\title{
RELAÇÕES FAMÍLIA - TRABALHO E CONCILIAÇÃO DE PAPÉIS DE GÊNERO
}

\section{Ana Carolina G. S. Santos Moreira ${ }^{1}$ Elisa Maria Andrade Brisola ${ }^{2}$}

Resumo: O texto objetiva a refletir sobre as relações familia-trabalho, a divisão sexual do trabalho e as relações de gênero. São abordadas estas relações partindo de uma breve introdução, seguida de uma reflexão sobre gênero como construção social e a divisão sexual do trabalho, na qual a mulher ocupa espaços de trabalho precarizados e mal (ou não) remunerados, buscando ainda conciliar as tarefas domésticas ao trabalho formal (ou informal). A partir das reflexões apontadas pelos autores, percebe-se que apesar do aumento da participação da mulher no mercado de trabalho, seu papel de protagonista nas atividades relacionadas ao cuidar, seja nas tarefas domésticas ou em suas profissões se mantém, demonstrando a manutenção de uma cultura arcaica e patriarcal.

Palavras-chave: Divisão sexual do trabalho; Família; Gênero.

\footnotetext{
1 Mestranda em Desenvolvimento Humano. Universidade de Taubaté - SP, Brasil. E-mail: anacarolina.moreira@outlook.com.

2 Professora assistente no Curso de Mestrado em Desenvolvimento Humano. Universidade de Taubaté - SP, Brasil. E-mail: elisabrisola@gmail.com.
} 